DOI https://doi.org/10.30525/978-9934-588-90-7-21

\title{
«ДІВЧА НА КОНІ»: ТРИ ІСТОРІЇ «БОЖЕВІЛЛЯ»
}

\author{
Кметь В. С. \\ кандидат філологічних наук, \\ бібліотекар першої категорії \\ Наукова бібліотека \\ Львівського наџіонального університету імені Івана Франка \\ м. Львів, Украӥна
}

Доба fin de siècle - не просто період зламу століть, а доба розчарувань та апокаліптичних візій, втоми та меланхолії, яка нависла над людиною. Саме про таку тугу писав М. Рудницький - “своєрідну мелянхолію, навислу тоді над европейською літературою з нової доби Weltschmerz щось наче жаль до світу, що він не признає ідеалів, - нахил зазначувати таємничість чи незглибність життя нарікати на незавидне становище непересічної одиниці серед пересічного загалу" [8, с. XVIII]. Ця світоглядна криза спровокувала цікаве й водночас неоднозначне явище у літературі й мистецтві - нову рецепцію образу жінки у суспільнокультурному дискурсі, подекуди обрамлюючи іiі постать у демонічні шати. У цьому дослідженні проаналізовано три надзвичайно цікаві в контексті демонізації образу жінки тексти-маркери, які були творчим відгуком на одне з відомих полотен польського художника Владислава Подковінського “Шал” (1894р.). Експресивна робота із відверто еротичним сюжетом спричинила неабиякий резонанс як серед поціновувачів мистецтва, так і колег маляра. Скандальна картина стала поштовхом для написання не менш яскравих художніх текстів: три авторські рецепції образу демонізованої жінки-вершниці - Михайла Яцківа “Дівчина на чорному коні”, Дарії Віконської “Шал” і Миколи Вороного “Дівча на коні”.

На картині превалює контраст чорного та бруднозеленого кольорів сполоханого, із розбурханою гривою вороного коня, що став на диби, сідлає оголена рудоволоса жінка. Мотив оголеності у цьому випадку варто інтерпретувати як ознаку належності до інферни, який, згідно із народно-демонологічними віруваннями, з'являється під час виконання магічного ритуалу. Образ коня також є лімінальним символом, оскільки у фольклорі він часто позначає межову ситуацію та постає посередником між життям і смертю. Ініціація дорівнює перетворенню, переродженню зі стану профанного в сакральний: “Кінь ототожнюється з Космосом, і його 
жертва символізує (тобто відтворює) акт творіння" [4, с. 116]. Розбурханість коня, його колір, хаотичність, невпорядкованість, неспокій настрою картини - також вказівка на демонізм, темну сторону потойбіччя. Згадати хоча б відомі роботи дещо ранішого періоду швейцарського та англійського художника Генрі Фюзелі "Нічний жах" (1781р.), на яких серед мороку нічної темряви постають обриси коня із роздутими ніздрями та страшним поглядом, кінь зловіще визирає 3 тіні важких гардин над ліжком жінки. Це ніби межа між світами, постать тварини на зламі світу й водночас за лаштунками.

Образ демонічної тварини з'явився невипадково, оскільки модернізм часто апелював і збагачувався міфологічними символами. А процес становлення нової образності української модерністської літератури часто апелював до універсальних сюжетів, міфології та фольклору як до підгрунтя творення вербальної парадигми художнього твору $[5,147]$. Це явище яскраво ілюструє й образотворче мистецтво - твори Ю. Мегоффера (“Медуза”), Я. Мальчевського (“Медуза”, “Отруєний колодязь”), В. Подковіньського (“Шал”) тощо.

Візуальна демонологія маркує образ потойбічних постатей скуйовдженим та переплутаним волоссям, яке стоїть дибки, іноді перемішаним зі зміями, з рогами тощо [6, с. 67]. Розкидане волосся також i в рудої панни В. Подковінського. Вона зі солодкавою посмішкою обіймає коня за шию. Ї̈̈ спокій контрастує з експресивним поривом тварини, очі жінки заплющені, на обличчі прочитується двозначність i самозаглиблення. “Солодкава посмішка панни може свідчити про покору гонові коня, його розбурханості - полум'яному гонові назустріч Абсолюту, Стихії." - зауважує Дарія Віконська [1, с. 65]. "Румак символ демонічного гону, розгнузданих сил, величний зразок, єдиний у своєму роді. Але він не має вудил: чи не соромно тобі? Як інакше виглядала би ти верхи на ньому, тримаючи своїми малими ручками у вудилах поборену жагу, з головою гордо піднесеною над сталевим тілом" - писала Д. Віконська в однойменному творі “Шал” [1, с. 66]. Однак “дикий Пегас без крил”, що без вудил став на диби із рудоволосою панною верхи, застиг на мить, ніби над прірвою - візія "упавшого янгола", що тужить за світлом, і спокусниці-музи, яка віддалася демонічному шалові, ба більше - осідлала інфернальну істоту.

Містична муза до болю затискає в лещатах творчості нещасну душу митця у новелі “Дівчина на чорному коні” Михайла Яцкова. Через смерть вона відкриває артистові Даріану світ інферни: “3 великої вулиці вимела смерть все життя, в однім вікні стояв труп і дивився з-поза портьєри скляними очима вдолину” [9, с. 86]. Естетизація смерті як 
єдиної і водночас неминучої альтернативи для артиста, самотність, приреченість на муки та розкіш мистецького акту - панна на чорному коні забирає серце Даріана: “Ти дав мені серце, я беру його на той світ, а тобі не маю що лишити. Лишаю тобі у заповіті чари творчості, i се вистане на твоє самотнє смутне життя на сій землі” [9, с. 88].

Білатеральний образ панни-вершниці постає також у тексті Миколи Вороного - весняного вечора на вогненному обрії міста "виросла таємнича кінна постать" [2, с. 186]. Панну зображено в сонячному сяйві та з білою лілеєю в руці (алюзія Богородичного символу чистоти). Проте ясний образ поступово перетворюється на апокаліптичну постать, демонічну потвору з чорними кучерями та “кретинічним" усміхом - ось воно, справжнє обличчя життя [2, с. 186]. Лімінальний час (“було се чудового теплого вечора, як сонце заходило”) та межовий символ коня відкривають митцеві “дійсність прокляту” - саме життя [2, с. 186].

Відтак можна підсумувати, що переосмислення естетичних ідеалів у творчості письменників-модерністів спровокувало новий погляд на трактування образу жінки в українській літературі, а подекуди - іiі демонічної іпостасі, апелюючи до іiі деструктивного характеру. Часто атрибутами інфернального характеру жінки постає білатеральна тварина - кінь, а також межовий час розгортання сюжету й ознаки, що маркують демонічну іпостась жінки (невпорядкованість, хаотичність, еротизм, демонічний сміх тощо). Втім, така трансформація образу жінки спровокована кількома факторами, які окреслила у своїх дослідженнях М. Подраза-Квятковська: настрої доби (вплив філософії Ф. Ніцше та А. Шопенгауера), рух за емансипацію жінок, соціальні передумови. До того ж, як писала Соломія Павличко, демонізація жінки була спровокована й нежиттєздатністю теми любові в українських модерністів, які жінку перетворили на деструктивну демонічну силу: "У цій ненависті до жінок виявилася своєрідна імпотенція самої любовної теми, іiі формальних виявів" [7, с. 121]. Фатальною тема любові виявилась і для самого В. Подковінського, про що свідчать шрами на обличчі загадкової вершниці.

\section{Література:}

1. Віконська Д. Шал. Віконська Д. Жінка в чорному: етюди, поезї в прозі, нариси, діалоги ; Джеймс Джойс: тайна його мистеиького обличчя / упорядкув., л-рна ред., передм. та прим. Василя Габора. Львів: ЛА "Піраміда", 2013. 108 с., 76 с.

2. Вороний М. Загадки життя (Фрагменти) І. Дівча на коні. Вороний М. Поезії. Переклади. Критика. Публічистика / [упоряд. і приміт. 
Т. І. Гундорової]. Київ: Наук. думка, 1996. С. 185-186. (Б-ка укр. л-ри. Укр. новіт. л-ра).

3. Гундорова T. Femina Melancholica: стать і культура в гендерній утопії Ольги Кобилянської. Київ: Критика, 2002. 272 с. (Сер. “Критичні студії”).

4. Еліаде М. Трактат з історії релігій / пер. 3 фр. Олексія Панича. Київ: Дух і Літера, 2016. 520 с.

5. Ільницький М. У руслі сецесійности (Синтез мистецтв у новелістиці Михайла Яцкова). Записки Наукового товариства імені Шевченка. T. CCLVII. Прачі Філологічної секиії. Львів, 2009. С. 147-174.

6. Махов А. Средневековый дьявол : трансформация визуальных маркеров демонического в "Иконологии" Чезаре Рипы. Третья научная конференция "Демонология как семиотическая система", Москва, РГГУ 15-17 мая 2014 2. Тезисы докладов; РГГУ, Центр типологии и семиотики фольклора, Отд-ние сочиокультурных исслед. - Москва: [РГГУ], 2014. С. 66-69.

7. Павличко С. Теорія літератури. Київ: Вид-во Соломії Павличко “Основи”, 2002. 679 с.

8. Рудницький М. Що таке “Молода Муза"? Чорна Індія “Молодої Музи”. Новелі / з передм. М. Рудницького. Львів, 1937. С. V-XVIII. (Б-ка “Діла"; ч. 18).

9. Яцків М. Дівчина на чорнім коні. Антологія украӥнської готичної прози: у 2 m. / уклад. Юрій Винничук. Харків : Фоліо, 2014. С. 85-89.

DOI https://doi.org/10.30525/978-9934-588-90-7-22

\title{
КОНЦЕПТ СПОКІЙ У РОМАНІ Е. ІІЛБЕРТ «ПРИРОДА ВСІХ РЕЧЕЙ»
}

\author{
Кохан Р. А. \\ кандидат філологічних наук, \\ доиент кафедри іноземних мов для природничих факультетів \\ Львівський національний університет імені Івана Франка \\ м. Львів, Україна
}

Сучасний гуманітарний простір, одночасним суб'єктом та об'єктом функціонування якого є людина, тяжіє до стохастичного нагромадження чи, радше, нашарування різновекторних смислів, ключових для синергетичного впорядкування духовної сфери людського буття. Знання 